\section{Application of a Biosolid Soil Amendment, Calcium Hydroxide, and Streptomyces for Management of Root-knot Nematode on Cantaloupe}

\author{
Susan L.F. Meyer ${ }^{1}$, Inga A. Zasada ${ }^{1}$, Mario Tenuta ${ }^{2}$, and \\ Daniel P. Roberts ${ }^{3}$
}

\begin{abstract}
AdDITIONAL INDEX WORDs. beneficial microbes, Cucumis melo, integrated pest
\end{abstract} management, Meloidogyne incognita, N-Viro Soil ${ }^{\mathrm{TM}}$

\begin{abstract}
Summary. The biosolid soil amendment N-Viro Soil (NVS) and a Streptomyces isolate (S 99-60) were tested for effects on root-knot nematode [RKN (Meloidogyne incognita)] egg populations on cantaloupe (Cucumis melo). Application of 3\% NVS (dry weight amendment/dry weight soil) in the soil mixture resulted in significant $(P \leq 0.01)$ suppression of RKN egg numbers on cantaloupe roots compared to all other treatments, including $1 \%$ NVS and untreated controls. Ammonia accumulation was higher with the 3\% NVS amendment than with any other treatment. Adjustment of soil $\mathrm{pH}$ with calcium hydroxide $\left[\mathrm{Ca}(\mathrm{OH})_{2}\right]$ to the same levels that resulted from NVS amendment did not suppress nematode populations. When cultured in yeast-malt extract broth and particularly in nutrient broth, S 99-60 was capable of producing a compound(s) that reduced RKN egg hatch and activity of second-stage juveniles. However, when this isolate was applied to soil and to seedling roots, no suppression of $\mathrm{RKN}$ egg populations was observed on cantaloupe roots. Combining S 99-60 with NVS or $\mathrm{Ca}(\mathrm{OH})_{2}$ did not result in enhanced nematode suppression compared to treatments applied individually. The results indicated that NVS application was effective at suppressing $\mathrm{RKN}$ populations through the accumulation of ammonia to levels lethal to the nematode in soil.
\end{abstract}

$\mathrm{R}$ oot-knot nematodes (Meloidogyne spp.) are major pathogens of crop plants worldwide and cause extensive damage on a number of economically important hosts, including melon (Koenning et al., 1999; Netscher and Sikora, 1990). High preplant populations of the root-knot nematode $M$. incognita can result in reduced melon fruit yields (Ploeg and

${ }^{1}$ USDA-ARS, Nematology Laboratory, Henry A. Wallace Beltsville Agricultural Research Center (BARC)West, Bldg. 011A, Rm. 165B, 10300 Baltimore Ave., Beltsville, MD 20705-2350; e-mail: meyerf@ba.ars. usda.gov

${ }^{2}$ Department of Soil Science, University of Manitoba, Winnipeg, MB, R3T 2N2, Canada.

${ }^{3}$ USDA-ARS, Sustainable Agriculture Systems Laboratory, Henry A. Wallace Beltsville Agricultural Research Center(BARC)-West, 10300 Baltimore Ave., Beltsville, MD 20705-2350.

Acknowledgments. The authors thank Paula Crowley, Stephen Rogers, Daphney Legros, Joshua Hanna, and Laurie McKenna for assistance with laboratory and greenhouse work, and Bryan Vinyard (Biometrical Consulting Service) for assistance with statistical analysis

Mention of trade names or commercial products in this publication is solely for the purpose of providing specific information and does not imply recommendation or endorsement by the U.S. Department of Agriculture.
Phillips, 2001). To decrease economic losses caused by RKN, innovative methods for managing these nematodes are needed in melon production. The current study was therefore conducted to evaluate the efficacy of a biosolid amendment and a beneficial microbe for management of RKN populations on cantaloupe.

The biosolid amendment used in this study was N-Viro Soil (NViro International, Toledo, Ohio). The N-Viro process mixes dewatered municipal biosolids with alkaline admixtures (i.e., cement kiln dust, fly ash or quicklime) to yield a pathogen-free, solid material with many beneficial agronomic properties (Logan and
Burnham, 1995). The agricultural value-added benefits of NVS include improved soil fertility, addition of organic matter and suppression of plant-parasitic nematodes (Welacky and Topp, 2001; Zasada and Tenuta, 2004).

In laboratory tests, the lethal concentration of NVS that killed 90\% $\left(\mathrm{LC}_{90}\right)$ of second-stage juvenile (J2) populations was $1.4 \%$ dry weight amendment/dry weight sand for RKN and soybean cyst nematode $[\mathrm{SCN}$ (Heteroderaglycines) $]$. The $\mathrm{LC}_{90}$ values for eggs were $2.6 \%$ and $>3.0 \%$ NVS for RKN and SCN, respectively (Zasada and Tenuta, 2004). Nematode mortality caused by NVS was positively correlated with sand suspension $\mathrm{pH}$ levels and to a lesser extent with ammonia accumulation following amendment (Zasada, 2005; Zasada and Tenuta, 2004). Greenhouse and field experiments have also demonstrated some suppression of SCN with NVS (Alptekin, 2001; Welacky and Topp, 2001).

The beneficial microbe examined in this study as a potential biocontrol agent for RKN was an isolate of the bacterium Streptomyces. Species of Streptomyces are well known to produce many antibiotics (Challis and Hopwood, 2003). Some of these antibiotics, such as avermectins and related compounds, are active against plant pathogens, including phytopathogenic nematodes (e.g., Blackburn et al., 1996; Cayrol et al., 1993; Jansson and Rabatin, 1998). Beneficial species of Streptomyces have been widely investigated for management of plantpathogenic fungi, and are marketed under names such as Actinovate $(S$. lydicus; Natural Industries, Houston) and Mycostop (S.griseoviridis; Verdera Oy, Helsinki, Finland) (APS Biological Control Committee, 2003). Species of Streptomyces have also been tested as potential biocontrol agents for nematodes. Research with RKN has yielded varying but often positive results from

\begin{tabular}{llll}
\hline $\begin{array}{l}\text { Units } \\
\text { To convert U.S. to SI, } \\
\text { multiply by }\end{array}$ & U.S. unit & SI unit & $\begin{array}{l}\text { To convert SI to U.S., } \\
\text { multiply by }\end{array}$ \\
\hline 29.5735 & $\mathrm{fl} \mathrm{oz}$ & $\mathrm{mL}$ & 0.0338 \\
3.7854 & $\mathrm{gal}$ & $\mathrm{L}$ & 0.2642 \\
2.5400 & inch $(\mathrm{es})$ & $\mathrm{cm}$ & 0.3937 \\
28.3495 & $\mathrm{oz}$ & $\mathrm{g}$ & 0.0353 \\
$\mathrm{l}$ & $\mathrm{ppm}$ & $\mathrm{mg} \cdot \mathrm{kg}^{-1}$ & 1 \\
2.2417 & ton/acre & $\mathrm{t} \cdot \mathrm{ha}^{-1}$ & 0.4461 \\
$\left({ }^{\circ} \mathrm{F}-32\right) \div 1.8$ & ${ }^{\circ} \mathrm{F}$ & ${ }^{\circ} \mathrm{C}$ & $\left(1.8 \times{ }^{\circ} \mathrm{C}\right)+32$ \\
& & &
\end{tabular}


laboratory, greenhouse, and field tests (Chubachi et al., 1999; Dicklow et al., 1993; El-Sherif et al., 1995; Krechel et al., 2002; McSorley and McGovern, 2001). The current study focused on a Streptomyces isolate (S 99-60) that had shown some activity against soilborne plant-pathogenic fungi (Roberts et al., 2005 ). If the isolate was also found to be efficacious for suppressing plantparasitic nematodes, it would be particularly useful as a biocontrol agent, because plants are usually challenged by multiple pathogens.

The specific objectives of this study were to determine: 1) how an NVS amendment affected soil $\mathrm{pH}$, ammonia accumulation and plant growth in amended soil; 2 ) if S 99-60 produced compounds toxic to RKN; and 3 ) whether nematode suppression on cantaloupe roots would occur in greenhouse trials with NVS amendment, S 99-60 application, increased $\mathrm{pH}$ level without the presence of NVS (and consequently without ammonia accumulation), or combinations of these agents.

\section{Materials and methods}

Culture of Streptomyces ISOLATE 99-60. Streptomycesisolate 99-60 was obtained from wheat rhizosphere in a field in Warsaw, Va., and maintained in the USDA-ARS, Sustainable Agriculture Systems Laboratory, Beltsville, $\mathrm{Md}$. To assay for production of compounds toxic to RKN, S 99-60 was grown for 3 and $9 \mathrm{~d}$ in $50 \mathrm{~mL}$ nutrient broth [NB (Difco; Becton, Dickinson and Co., Sparks, Md.)] or yeast extract broth containing malt extract [YME (Pridham et al., 1957)]. Cultures were maintained at room temperature and $200 \mathrm{rpm}$ in $250-\mathrm{mL}$ Erlenmeyer flasks. Biomass was then removed by centrifugation $(9150 \times g$ for $20 \mathrm{~min}$ at $4{ }^{\circ} \mathrm{C}$ ) and the culture supernatant was filtered through $0.2-\mu \mathrm{m}$ bottle filters. The $\mathrm{pH}$ of each culture filtrate was recorded.

To prepare S 99-60 for greenhouse studies, the bacterium was grown on potato dextrose agar (Difco) and then inoculated into two 1-L baffled flasks, each containing $500 \mathrm{~mL}$ of YME. The flasks were placed in a rotary shaker and incubated for $4 \mathrm{~d}$ at $30^{\circ} \mathrm{C}$ and $230 \mathrm{rpm}$. After $4 \mathrm{~d}, 166 \mathrm{~mL}$ of $\mathrm{S}$ 99-60 YME culture were placed into each of six new flasks, and an additional $334 \mathrm{~mL}$ YME were then added to each of the six flasks to make a total volume of $500 \mathrm{~mL}$ per flask. The cultures in the six flasks were incubated $8 \mathrm{~d}$ at 30 ${ }^{\circ} \mathrm{C}$ and $230 \mathrm{rpm}$ in the rotary shaker. The cultures were then centrifuged for $30 \mathrm{~min}$ at $13,200 \times \mathrm{g}$. A total of $70 \mathrm{~g}$ wet S 99-60 biomass were collected and blended in a commercial blender on low for $15 \mathrm{~s}$ in $500 \mathrm{~mL}$ water, and the bacterial suspension was then diluted in a total of $3 \mathrm{~L}$ water. This suspension contained about $5.4 \times 10^{7}$ spores per $\mathrm{mL}$.

Culture of RKN. Meloidogyne incognita race 1 , originally isolated from a field near Salisbury, Md., was cultured in the USDA-ARS, Nematology Laboratory greenhouse (Beltsville, Md.) on pepper (Capsicum annuum) cultivar PA-136. For microwell assays, RKN was prepared as described by Nitao et al. (1999, 2002), with the following differences: RKN was cultured on greenhouse-grown pepper plants, and eggs were surface-sterilized in $0.5 \%$ sodium hypochlorite for $4 \mathrm{~min}$. Eggs for greenhouse experiments were extracted from the roots of 3 -month-old pepper plants and used immediately.

MICROWELl ASSAYS FOR PRODUCTION OF TOXIC COMPOUNDS BY S 9960. Procedures were similar to those described in Meyer et al. (2004). Following preparation of culture filtrates, $0.9 \mathrm{~mL}$ of culture filtrate or control, and $0.1 \mathrm{~mL}$ aqueous suspension of surface-sterilized nematode eggs (about 470 eggs), were placed into individual wells of 24-well tissue culture plates (Costar, Corning, N.Y.), for a total volume of $1 \mathrm{~mL} /$ well. The following seven treatments were tested: 1) sterile water control, 2) sterile YME control, 3 ) sterile NB control, 4) YME culture filtrate after 3 d S 99-60 growth, 5) YME culture filtrate after $9 \mathrm{~d} S$ 99-60 growth, 6) NB culture filtrate after 3 d S 99-60 growth, and 7) NB culture filtrate after 9 d S 99-60 growth. The sterile water controls were used to determine viability of the eggs and $\mathrm{J} 2$. After $7 \mathrm{~d}$ incubation at $28^{\circ} \mathrm{C}$, the total number of hatched $\mathrm{J} 2$ in each well was counted to determine egg hatch. At the same time, each hatched J2 was also counted as active or inactive. J2 were counted as active if they exhibited any movement when observed with light microscopy, and inactive if no movement was observed. No probe was applied to initiate movement. Five replicate wells were used for each treatment, and the experiment was conducted twice.
Greenhouse studies. A soil composed of 1:5 compost:sand mixture, $\mathrm{pH} 7.6$, was steamed and then treated with NVS ( $\mathrm{pH} 12.2$ in water), or $\mathrm{Ca}(\mathrm{OH})_{2}$, or left untreated. NVS was incorporated at $1 \%$ and $3 \%$ dry weight amendment/dry weight soil (w/w). $\mathrm{Ca}(\mathrm{OH})_{2}$ was applied to the soil at $0.05 \%$ and $0.08 \% \mathrm{Ca}(\mathrm{OH})_{2}(\mathrm{w} / \mathrm{w})$; these rates were previously determined to achieve comparable $\mathrm{pHs}$ to those measured after the NVS amendments. The amended or unamended soil was placed into l-quart sealable plastic bags ( $450 \mathrm{~g}$ per bag) and moistened to $70 \%$ of water holding capacity (Cassel and Nielsen, 1986); 5000 RKN eggs were then inoculated into half of the bags from each treatment. The bags were sealed and the contents were gently mixed. The sealed bags were placed in the dark at approximately $24{ }^{\circ} \mathrm{C}$ for $5 \mathrm{~d}$.

Cantaloupe 'Hearts of Gold' seeds were planted in flats of Terra-Lite Redi-Earth Peat Lite mix (ScottsSierra Horticultural Products Co., Marysville, Ohio), and the seeds were germinated on propagation mats $(21$ to $27^{\circ} \mathrm{C}$ ) in a greenhouse maintained at temperatures between 24 and 29 ${ }^{\circ} \mathrm{C}$. Flats were removed from the propagation mats after $5 \mathrm{~d}$. Natural and supplemental lighting were combined to achieve a 16-h day length. Seedlings were transplanted $18 \mathrm{~d}$ after planting. Immediately prior to transplanting, soil treatments in plastic bags were mixed with either $5 \mathrm{~mL} \mathrm{~S}$ 99-60 suspended in water, or $5 \mathrm{~mL}$ water. The soil in each bag was placed into a 4 -inch-diameter pot, and another 5 mL S 99-60 suspension was added to soil already treated with S 99-60. All other pots received an additional $5 \mathrm{~mL}$ water. At transplant, the root systems from all plants were rinsed in water. Roots of seedlings to be transplanted into soil treated with S 99-60 were then dipped into an aqueous suspension of $S$ 9960 (about $2 \mathrm{~mL}$ suspension adhered to each root system), while all other seedlings were dipped in water. One cantaloupe seedling was transplanted into each pot. Plants were fertilized with 3 g Osmocote Plus 15N-3.9P$10 \mathrm{~K}$ fertilizer (Scotts-Sierra) $8 \mathrm{~d}$ after transplanting, and harvested $30 \mathrm{~d}$ (trial 1) or $33 \mathrm{~d}$ (trial 2) after transplant.

The greenhouse experiment was conducted twice, for a total of two trials. Ten pots were planted per treatment in the first experimental 
trial, and 12 pots were planted per treatment in the second trial (only 10 pots per treatment were used for data collection in the second trial, so there were 20 replications per treatment when the two trials were combined). The pots in each trial were arranged in a completely randomized design. There were 20 treatments per trial: 1 ) untreated soil; 2 and 3$) 1 \%$ NVS $\pm S$ $99-60 ; 4$ and 5$) 3 \%$ NVS $\pm S$ 99-60; 6 and 7$) 0.05 \% \mathrm{Ca}(\mathrm{OH})_{2} \pm \mathrm{S} 99-60 ; 8$ and 9$\left.) 0.08 \% \mathrm{Ca}(\mathrm{OH})_{2} \pm \mathrm{S} 99-60 ; 10\right)$ S 99-60; and 11-20) all 10 treatments repeated with nematode inoculum added. The treatment structure was a $5 \times 2 \times 2$ factorial.

At harvest, shoot heights were measured from the soil line to the tips of the main stems. Shoot dry weights (all plant parts above the soil line) were determined after removal of the shoots from the pots and oven-drying for 15 $\mathrm{d}$ at $74^{\circ} \mathrm{C}$. Soil and roots from each pot were collected and placed in a cold room $\left(4^{\circ} \mathrm{C}\right)$ until processing for root weights and RKN egg counts. Root fresh weights were determined; root dry weights were not used because roots were destroyed in the process of collecting nematode eggs.

RKN egg collection and enumeration were similar to previously described procedures (Nitao et al., 2002; Meyer et al., 2000), with the following exceptions: eggs were not counted from soil outside the rhizosphere, and roots were macerated with scissors and then in a mini food processor. Eggs external to roots were labeled "external eggs," and eggs inside plant roots were labeled "internal eggs." All aqueous egg suspensions were refrigerated until counted. Aliquots were counted to estimate numbers of internal and of external eggs per gram of fresh root, and these numbers were combined to estimate total numbers of eggs per gram of fresh root.

To determine presence or absence of S 99-60 in the soil at harvest, $5 \mathrm{~g}$ of soil were removed from each of two pots per treatment and suspended in $25 \mathrm{~mL}$ water, and $1 \mathrm{~mL}$ of the suspension was then diluted in $9 \mathrm{~mL}$ water. Each suspension was plated onto two YME plates.

SOIL AMMONIA AND PH MEASUREMENTS. From all of the bags not inoculated with nematodes, soil slurry $\mathrm{pH}$ was measured at 1,5 , and $30 \mathrm{~d}$ after treatment. Five grams of soil were removed from each bag and placed in a
$50 \mathrm{~mL}$ tube, and $20 \mathrm{~mL}$ distilled water added. The slurry was agitated using a reciprocal shaker at $350 \mathrm{rpm}$ for 15 min, the supernatant was allowed to clear for $15 \mathrm{~min}$, and the $\mathrm{pH}$ of the supernatant was then determined.

In a separate experiment, $15 \mathrm{~g}$ portions of the soil mix were amended to $1 \%$ or $3 \%$ NVS, or $0.05 \%$ or $0.08 \%$ $\mathrm{Ca}(\mathrm{OH})_{2}$, and placed in $50-\mathrm{mL}$ tubes. An untreated control wasincluded. Distilled water was added to the mixtures to achieve $70 \%$ water-holding-capacity, and the tubes were sealed and placed at $24^{\circ} \mathrm{C}$ for $\mathrm{l} \mathrm{h}$. The tubes were then placed in a cold room $\left(4^{\circ} \mathrm{C}\right)$ and all subsequent sample preparations were performed at this temperature in sealed vessels containing minimal headspace to limit ammonia loss. Fifteen milliliters cold deionized water were added to each tube and the tubes were agitated using a reciprocal shaker at $350 \mathrm{rpm}$ for $30 \mathrm{~min}$, and then were allowed to stand for $5 \mathrm{~min}$. The $\mathrm{pH}$ of each slurry supernatant was then determined. For ammonium plus ammonia analysis, $1 \mathrm{~mL}$ of the slurry supernatant was removed and passed through a 0.2um filter into a 1.5-mL Eppendorf tube. The ammonia plus ammonium concentration of the filtered slurry supernatant was measured using a colorimetric method utilizing the Berthelot reaction (Rhine et al., 1998). Ammonia concentration in soil slurry was estimated using the HendersonHasselbach equation describing the $\mathrm{pH}$-dependent equilibrium between ammonium and ammonia (Tenuta and Lazarovits, 2002a). The experiment was repeated twice.

Statistical analysis. Data from the greenhouse studies were analyzed using SAS release 9.1 (SAS Institute, Cary, N.C.). Prior to analysis the appropriate variance groups were assigned to treatments. A mixed linear model was used to determine the significance of main effects and interactions between main effects and treatment effects. Experimental trials were combined. Means were separated using Sidak $P$-value adjustments for multiple comparisons $(P \leq 0.01)$. For microwell assays, mean total numbers of hatched J2 from all treatments were separated by an F-protected least significant difference (LSD) at $P$ $\leq 0.05$ using a general linear model. The two trials were combined prior to analysis. Mean numbers of active and inactive $\mathrm{J} 2$ with standard deviations were determined for each treatment. For comparisons of $\mathrm{J} 2$ activity among treatments, proportions of active to inactive $\mathrm{J} 2$ were determined as (active - inactive)/inactive J2.

\section{Results}

Microwell assays. In three of the four culture filtrate treatments, $S$ 99-60 produced a compound(s) that suppressed RKN egg hatch (Fig. 1). Culture filtrate from S 99-60 grown in YME for $3 \mathrm{~d}$ was the one exception; this treatment appeared to stimulate egg hatch, and resulted in the highest total numbers of hatched J2. The next highest numbers of hatched J2 were in the YME and NB controls, followed by the water control. Conversely, treatment of eggs with culture filtrate from YME after 9 d S 99-60 growth resulted in a significant decrease in the total numbers of hatched $\mathrm{J} 2$ compared to the 3-d YME culture filtrate, and to the water, NB and YME controls. Culture filtrate from S 99-60 grown in NB for either 3 or $9 \mathrm{~d}$ contained a compound(s) that highly suppressed RKN egg hatch, with total numbers of hatched J2 in the sterile NB control 7.1 to 10.8 times greater than in the $\mathrm{NB}$ culture filtrates.

Effects of culture filtrates on $\mathrm{J} 2$ activity were somewhat similar to the results with egg hatch, with a trend toward greater J2 activity generally occurring in treatments with the highest egg hatches (Fig. 1). However, the mean proportion of active to inactive $\mathrm{J} 2$ was significantly higher in the water control than in any other treatment, including filtrate from 3-d-old S 99-60 cultures in YME. Numbers of active and inactive $\mathrm{J} 2$ were not different from each other in either of the two YME culture filtrates. Of the small numbers of $\mathrm{J} 2$ that hatched from eggs in NB culture filtrates, few were active in the 3 -d NB culture filtrate, and only one $\mathrm{J} 2$ was active in the 9-d NB culture filtrate. The proportion of active to inactive J2 in S 99-60 culture filtrate grown for 9-d in NB was significantly lower than the proportion in any of the controls.

Greenhouse studies. Numbers of internal, external and total eggs per gram fresh root were strongly affected by treatment with NVS (Fig. 2). Numbers of eggs produced internally and externally, and consequently total numbers of eggs, were lowest with the $3 \%$ NVS treatment, with or without 


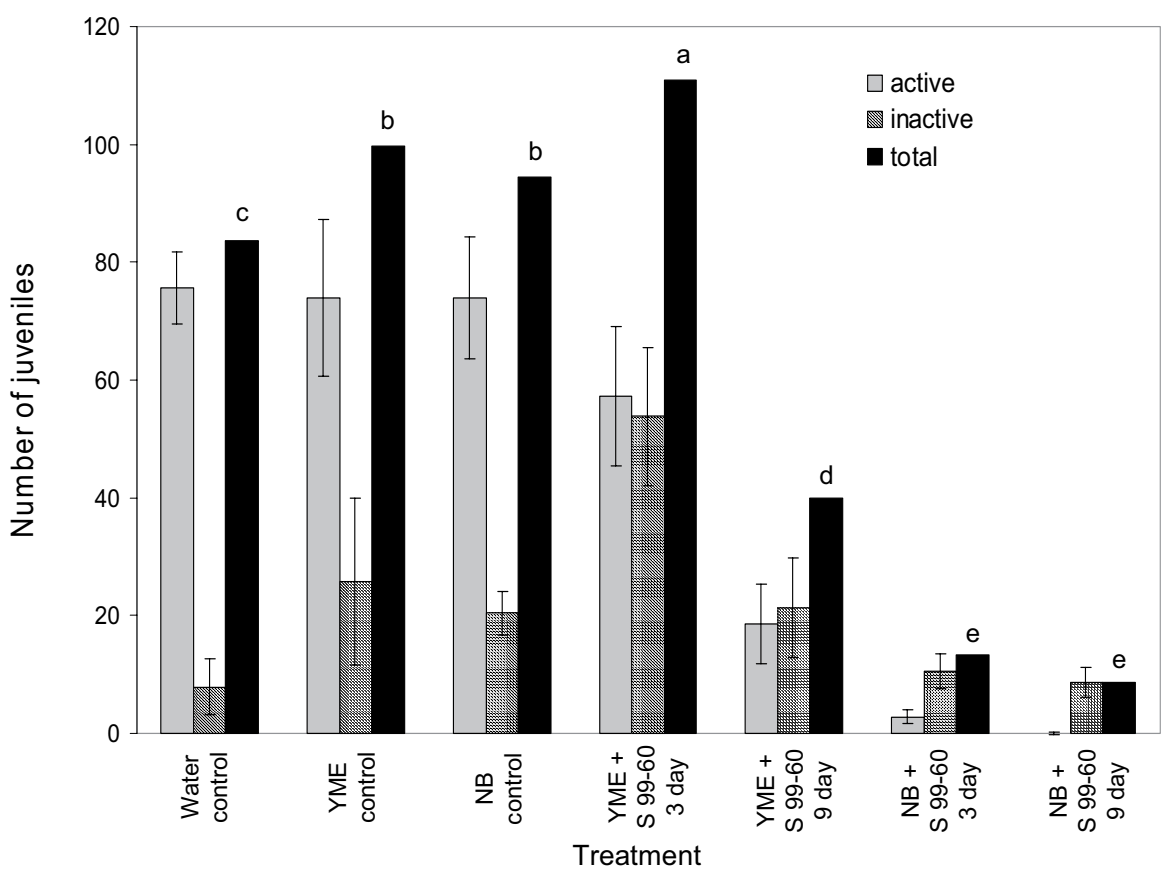

Fig. 1. Effects of Streptomyces (S 99-60) culture filtrates on total numbers of hatched root-knot nematode (RKN) second-stage juveniles (J2), and on activity of the hatched $\mathrm{J} 2$ in microwell assays. YME = yeast-malt extract broth; $\mathrm{NB}=\mathbf{n u}$ trient broth. Numbers of hatched J2, and of active vs. inactive J2, were counted $7 \mathrm{~d}$ after placement of eggs into water, broth controls, or culture filtrates from $S$ 99-60 grown for either 3 or $9 \mathrm{~d}$ in YME or NB. Each well received about 470 eggs; values shown are from two trials, each with five replicate wells per treatment ( $\mathrm{n}=10$ per treatment). "Total" J2 means with different letters were significantly different $(P \leq 0.05)$. Standard deviation bars represent one standard deviation from the mean and indicate differences between active and inactive $\mathrm{J} 2$ within a treatment.

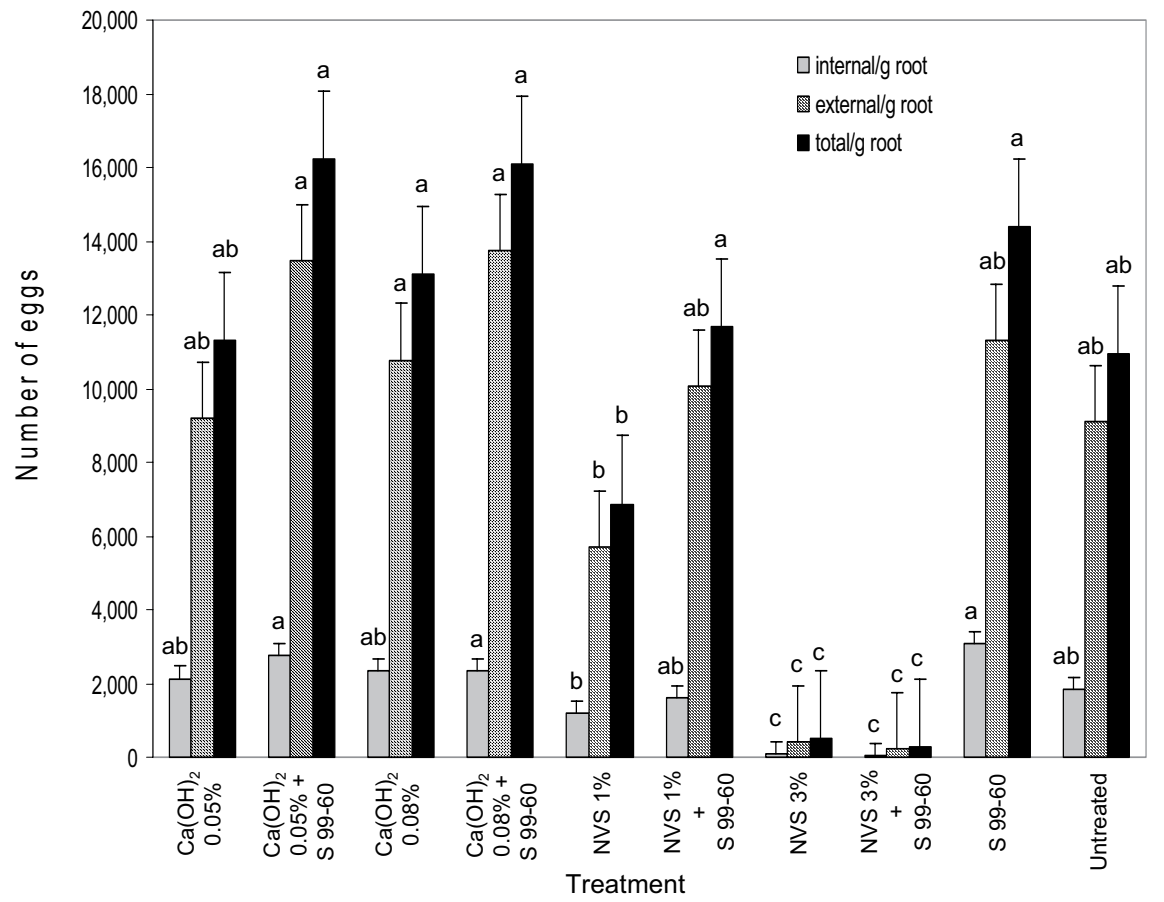

S 99-60. Amendment with 1\% NVS alone also resulted in total egg numbers lower than numbers in several other treatments, although the total egg numbers were not lower than those in untreated soil or in $0.05 \% \mathrm{Ca}(\mathrm{OH})_{2}$. Amendment with 1\% NVS resulted in lower total egg numbers than treatment with $1 \%$ NVS + S 99-60, indicating that S 99-60 may have negated the effects of $1 \%$ NVS on the egg populations. Treatment with $\mathrm{Ca}(\mathrm{OH}){ }_{2}$ or S 99-60 (except 3\% NVS + S 99-60) did not suppress egg numbers compared to the untreated control.

Analysis of shoot heights and dry weights indicated that there was no effect due to S 99-60 inoculation, so similar treatments with and without S 99-60 were combined for statistical analysis (Table 1). There was some tendency for shoots to be longer in plants not inoculated with RKN when compared with identically treated plants inoculated with RKN, but this was not statistically significant, and was reversed in shoot heights from untreated controls. Treatment with $1 \%$ NVS tended to result in the longest and heaviest shoots, while shoots that were small in both height and weight were recorded from $3 \% \mathrm{NVS}$ and $0.08 \%$ $\mathrm{Ca}(\mathrm{OH})_{2}$, both plus RKN.

Plants inoculated with RKN tended to have heavier root systems than plants not inoculated with nematodes. The range of mean root fresh weights from each treatment was $6.5 \mathrm{~g}$ to 10.0 $\mathrm{g}$ for uninoculated plants, while the range for plants infested with RKN was $7.2 \mathrm{~g}$ to $12.3 \mathrm{~g}$. However, there was overall no effect among treatments with or without RKN or S 99-60, and the data were combined. Treatment with

Fig. 2. Effects of treatment with $\mathrm{N}$ Viro Soil (NVS), calcium hydroxide $\left[\mathrm{Ca}(\mathrm{OH})_{2}\right]$, Streptomyces (S 99-60), or combinations of either NVS or $\mathrm{Ca}(\mathrm{OH})_{2}+\mathrm{S} 99-60$ on root-knot nematode (RKN) egg populations from greenhouse-grown cantaloupe roots. Internal = number of eggs inside roots; external $=$ number of eggs in the rhizosphere; total = external + internal eggs. Numbers are eggs/g $\operatorname{root}(1 \mathrm{~g}=0.0353 \mathrm{oz})$. Within each egg category (internal, external, and total eggs per gram of root), values with the same letter were not significantly different $(P \leq \mathbf{0 . 0 1})$. Error bars represent SE. 
Table 1. The effects of N-Viro Soil (NVS), calcium hydroxide $\left[\mathrm{Ca}(\mathrm{OH})_{2}\right]$, and root-knot nematode ( $\mathrm{RKN})$ infestation on shoot growth of greenhouse-grown cantaloupe. Plants were harvested about $30 \mathrm{~d}$ after transplant of 18-d-old seedlings. Similar treatments with and without Streptomyces (S 99-60) were combined for analysis as this treatment did not affect measured parameters.

\begin{tabular}{lcc}
\hline Treatment & Shoot ht $(\mathbf{c m})^{\mathrm{z}}$ & ${\text { Shoot dry wt }(\mathbf{g})^{\mathrm{z}}}^{\text {NVS } 1 \%}$ \\
NVS 1\%+RKN & $87.1 \mathrm{a}$ & $3.6 \mathrm{a}$ \\
NVS 3\% & $79.8 \mathrm{abc}$ & $3.2 \mathrm{ab}$ \\
$\mathrm{NVS} \mathrm{3} \%+\mathrm{RKN}$ & $81.6 \mathrm{abc}$ & $2.6 \mathrm{~cd}$ \\
$\mathrm{Ca}(\mathrm{OH})_{2} 0.05 \%$ & $73.2 \mathrm{bc}$ & $2.5 \mathrm{~d}$ \\
$\mathrm{Ca}(\mathrm{OH})_{2} 0.05 \%+\mathrm{RKN}$ & $78.4 \mathrm{abc}$ & $3.1 \mathrm{abc}$ \\
$\mathrm{Ca}(\mathrm{OH})_{2} 0.08 \%$ & $73.5 \mathrm{c}$ & $3.1 \mathrm{abc}$ \\
$\mathrm{Ca}(\mathrm{OH})_{2} 0.08 \%+\mathrm{RKN}$ & $72.2 \mathrm{bc}$ & $3.3 \mathrm{ab}$ \\
Untreated & $72.1 \mathrm{c}$ & $2.5 \mathrm{~d}$ \\
Untreated $+\mathrm{RKN}$ & $79.2 \mathrm{abc}$ & $2.9 \mathrm{bcd}$ \\
\hline
\end{tabular}

${ }^{2}$ Values shown were from two trials, each with 10 replications per treatment $(n=20)$. Because treatments were combined, $\mathrm{n}=40$ for the analysis. Within a column, values followed by the same letter were not significantly different $(P \leq 0.01) ; \mathrm{l} \mathrm{cm}=0.3937$ inch, $1 \mathrm{~g}=0.0353 \mathrm{oz}$.
Table 2. The effects of N-Viro Soil (NVS) and calcium hydroxide $\left[\mathrm{Ca}(\mathrm{OH})_{2}\right]$ on root fresh weights of greenhouse-grown cantaloupe. after transplant of 18-d-old seedlings. Similar treatments with and without root-knot nematode ( $\mathrm{RKN})$, and with and without Streptomyces sp. (S 99$60)$, were combined for analysis as the treatments did not affect root fresh weight.

\begin{tabular}{lc}
\hline Treatment & Root fresh wt $(\mathbf{g})^{\mathrm{z}}$ \\
\hline NVS 1\% & $9.8 \mathrm{a}$ \\
NVS 3\% & $7.3 \mathrm{c}$ \\
$\mathrm{Ca}(\mathrm{OH})_{2} 0.05 \%$ & $9.4 \mathrm{ab}$ \\
$\mathrm{Ca}(\mathrm{OH})_{2} 0.08 \%$ & $9.3 \mathrm{ab}$ \\
Untreated & $8.3 \mathrm{bc}$ \\
\hline
\end{tabular}

${ }^{2}$ Values shown were from two trials, each with 10 rep lications per treatment $(\mathrm{n}=20)$. Because treatments were combined, $\mathrm{n}=80$ for the analysis. Values followed by the same letter were not significantly different $(P \leq$ $0.01) ; \mathrm{lg}=0.0353 \mathrm{oz}$.

$1 \%$ NVS resulted in the heaviest root system (Table 2); this treatment also had the largest shoots (Table 1). The lightest root systems were from the 3\% NVS treatment; small shoots were also produced from treatment with $3 \%$ NVS $+\mathrm{RKN}$, and small shoot weights from $3 \%$ NVS amendment with or without RKN (Table 1).

No S 99-60-like colonies were recovered from soil in trial 1 . In trial 2, only a few S 99-60-like colonies were recovered from a pot treated with $0.05 \% \mathrm{Ca}(\mathrm{OH})_{2}+\mathrm{S} 99-60+\mathrm{RKN}$, and from a pot treated with $1 \%$ NVS + S 99-60 + RKN.

AMmONIA AND PH MEASUREMENTS. Amendment of soil with NVS Plants were harvested about $30 \mathrm{~d}$ or $\mathrm{Ca}(\mathrm{OH})_{2}$ resulted in an immediate increase in $\mathrm{pH}$. Within $\mathrm{l} \mathrm{h}$ after addition of the amendments, the unamended soil pH was 7.5, while the $\mathrm{pH}$ values in soil amended with NVS or $\mathrm{Ca}(\mathrm{OH})_{2}$ ranged from 9.1 to 10.1 (Table 3 ). The higher rates of the amendments tended to raise the $\mathrm{pH}$ values more than the lower rates of the same amendments, although in the case of $\mathrm{Ca}(\mathrm{OH})_{2}$, the $\mathrm{pH}$ values of the higher and lower rates were not significantly different. The $\mathrm{pH}$ in each of the amended soils remained high after one $\mathrm{d}$, but dropped within $5 \mathrm{~d}$ after the treatments were added. After $30 \mathrm{~d}$, the amended and unamended soils all had similar $\mathrm{pH}$ values.

In amended soils, ammonia levels were lowest after amendment with $0.05 \%$ and $0.08 \% \mathrm{Ca}(\mathrm{OH})_{2}$, although the $0.08 \% \mathrm{Ca}(\mathrm{OH})_{2}$ amendment resulted in an ammonia level similar to that recorded with $1 \%$ NVS (Table 3 ). After $1 \mathrm{~h}$, amendment with $3 \%$ NVS than six times higher than amendment with $1 \%$ NVS.

\section{Discussion}

This is the first published report demonstrating that NVS has the capacity to suppress RKN populations on plant roots. NVS was toxic to RKN and to SCN in laboratory assays (Zasada, 2005; Zasada and Tenuta, 2004), and it could suppress SCN populations in greenhouse and field studies, although results were variable (Alptekin, 2001; Welacky and Topp, 2001). Our study demonstrates that the NVS effect extends to RKN egg populations on roots of greenhouse-grown cantaloupe, with significant suppression at the higher NVS application rate. Amendment with 3\% NVS reduced egg populations within the roots as well as in the rhizosphere. The activity against the nematodes presumably occurred prior to plant infection by the nematode, or was systemic.

The effect of NVS application on $\mathrm{pH}$ values and ammonia accumulation has been evaluated in prior studies (Zasada, 2005; Zasada and Tenuta, 2004). In our study, increasing soil pH with $\mathrm{Ca}(\mathrm{OH})_{2}$ to levels similar to those generated after NVS amendment did not suppress RKN egg populations, indicating that the high $\mathrm{pH}$ resulting from NVS amendment was not solely responsible for causing nematode mortality. The main chemical difference between soils treated with the two amendments appeared to be accumulation of ammonia. Ammonia levels were substantially higher with 3\% NVS than with any other treatment, including $1 \%$ NVS amendment, which did not result in the same level of resulted in an ammonia level more

Table 3. Soil slurry $\mathrm{pH}$ and ammonia $\left(\mathrm{NH}_{3}\right)$ levels (millimolar) after the incorporation of N-Viro Soil (NVS) or calcium hydroxide $\left[\mathrm{Ca}(\mathrm{OH})_{2}\right]$.

\begin{tabular}{|c|c|c|c|c|c|c|}
\hline \multirow[b]{2}{*}{ Treatment } & \multirow{2}{*}{$\begin{array}{c}\text { Rate } \\
(\% \text { dry } w / w)^{x}\end{array}$} & \multicolumn{4}{|c|}{$\begin{array}{c}\mathrm{pH}^{\mathrm{z}} \\
\text { Mean } \pm \mathrm{SD}^{\mathrm{y}}\end{array}$} & \multirow{2}{*}{$\begin{array}{l}\mathrm{NH}_{3} \\
(\mathrm{mM})^{\mathrm{w}}\end{array}$} \\
\hline & & $1 \mathrm{~h}$ & $1 \mathrm{~d}$ & $5 \mathrm{~d}$ & $30 \mathrm{~d}$ & \\
\hline Unamended & 0 & $7.5 \pm 0.1$ & $7.7 \pm 0.2$ & $7.8 \pm 0.1$ & $6.7 \pm 0.5$ & 0 \\
\hline $\mathrm{Ca}(\mathrm{OH})_{2}$ & 0.05 & $9.6 \pm 0.2$ & $9.7 \pm 0.5$ & $9.1 \pm 0.1$ & $7.3 \pm 0.3$ & $0.4 \pm 0.1$ \\
\hline $\mathrm{Ca}(\mathrm{OH})_{2}$ & 0.08 & $10.1 \pm 0.3$ & $10.2 \pm 0.4$ & $9.4 \pm 0.1$ & $7.3 \pm 0.3$ & $0.6 \pm 0.1$ \\
\hline NVS & 1 & $9.1 \pm 0.2$ & $9.3 \pm 0.3$ & $8.9 \pm 0.1$ & $7.4 \pm 0.4$ & $0.8 \pm 0.2$ \\
\hline NVS & 3 & $10.1 \pm 0.2$ & $10.2 \pm 0.4$ & $9.2 \pm 0.1$ & $7.6 \pm 0.3$ & $5.1 \pm 0.5$ \\
\hline
\end{tabular}

${ }^{2}$ For the 1 -h measurement, $\mathrm{pH}$ was determined on supernatant from a slurry of $15 \mathrm{~g}$ of amended or unamended soil in $15 \mathrm{~mL}$ water; for $1-, 5-$, and $30-\mathrm{d}$ measurements, $\mathrm{pH}$ was determined on supernatant from a slurry of $5 \mathrm{~g}$ soil in $20 \mathrm{~mL}$ water; $1 \mathrm{~g}=0.0353 \mathrm{oz} ; 1 \mathrm{~mL}=0.0338 \mathrm{fl} \mathrm{oz}$.

Values shown are the means of two experiments with five replications for each treatment $(\mathrm{n}=10)$. ${ }^{x_{\mathrm{W}} / \mathrm{w}}=$ weight of amendment/weight of soil.

" $\mathrm{NH}_{3}$ concentration estimated using Henderson-Hasselbach equation, $\mathrm{pH}$ and $\mathrm{NH}_{3}+\mathrm{NH}_{4}^{+}($ammonia plus ammonium) levels $\mathrm{l}$ h after amendment. 
nematode suppression. Increased levels of ammonia in soil were lethal to various pathogenic fungi and nematodes (Chun and Lockwood, 1985; Oka et al., 1993; Oka and Pivonia, 2002; 2003; Tenuta and Lazarovits, 2002a; Tsao and Oster, 1981). It is probable that the accumulation of ammonia in soil amended with 3\% NVS killed most of the RKN eggs during the 5-d incubation period prior to cantaloupe transplant into the amended soil. It is important to note that previous laboratory studies evaluating NVS for nematode suppression did not use a closed system (Zasada, 2005; Zasada and Tenuta, 2004). The closure of the bags after NVS amendment in this experiment means that $\mathrm{RKN}$ was exposed to higher ammonia concentrations for a longer period of time than in earlier investigations.

The largest plants were in soil amended with $1 \%$ NVS (particularly the plants without nematodes); enhanced soybean growth has been reported after a $4 \%$ NVS amendment to sand (Alptekin, 2001). The smallest plants overall were in soil amended with $3 \%$ NVS (especially when nematodes were present). Residual ammonia in soil, combined with high $\mathrm{pH}$, may have initially inhibited plant growth at the higher NVS amendment rate. High $\mathrm{pH}$ associated with NVS application may pose several challenges to crop production. $\mathrm{pH}$ levels above 8.5 may induce ammonia toxicity in soils receiving coincidently a source of ammoniacal fertilizer or having high residual ammonium. High $\mathrm{pH}$ can pose nutrient limitations to the crop, particularly phosphorus and micronutrients (e.g., iron). Thus NVS should be applied to soils capable of buffering the rise in $\mathrm{pH}$ following NVS application to levels below $\mathrm{pH} 8$ within days or several weeks after application. The nutrients found in a $1 \%$ NVS application rate may have enhanced plant growth; the NVS used in this study contained approximately $0.002 \mathrm{mg} / \mathrm{kg}$ plant available nitrogen, $0.008 \mathrm{mg} / \mathrm{kg}$ phosphorus, $0.002 \mathrm{mg} / \mathrm{kg}$ potassium, and $0.06 \mathrm{mg} / \mathrm{kg}$ sulfur. Measurements of yields in a field experiment would determine whether the RKN population reductions obtained with a high NVS amendment rate also translate to meaningful market increases.

The tested Streptomyces isolate, $S$ 99-60, produced a compound(s) toxic to RKN in laboratory assays, decreasing both egg hatch and $\mathrm{J} 2$ activity. There was an exception; filtrate from 3-d YME cultures increased numbers of hatched eggs. Toxic activity was particularly present in filtrates from NB cultures, and it is interesting to note that in preliminary trials, a volatile compound(s) produced by $S$ 99-60 grown in NB prevented hatch of most of the eggs in the assay plates, necessitating separation of treatments. Despite the capacity for toxin production, S 99-60 did not suppress $\mathrm{RKN}$ populations on cantaloupe in this study, nor in a test on cucumber in the greenhouse (S.L.F. Meyer and D.P. Roberts, unpublished). The greenhouse conditions may not have been right for S 99-60 to generate lethal levels of the nematotoxic compound(s). Also, despite the addition of large numbers of spores, S 9960-like colonies were rarely detected after harvest, which may also account for lack of efficacy in the greenhouse experiment. However, while some beneficial bacteria are aggressive root colonizers (Siddiqui and Mahmood, 1999), a strain of the fungus Lecanicillium lecanii (= Verticillium lecanii) that suppressed RKN egg numbers on roots of greenhouse-grown cantaloupe plants was not reisolated from soil at harvest (Meyer, 1999), indicating that long-term survival is not always necessary for suppression of RKN by beneficial microbes.

NVS rates of $1 \%$ and $3 \%$ correspond to field application rates of 20 and 60 dry t $\cdot \mathrm{ha}^{-1}$ per furrow slice $(\mathrm{Za}$ sada and Tenuta, 2004). The 3\% rate is extremely high for practical use by producers. However, where economically damaging levels of RKN occur in patches within fields, spot application with higher rates may be considered. Also, in crops applied on raised beds, it may be practical to apply higher rates of NVS to the bedded areas of the field. Research is underway combining NVS treatment with other control strategies to reduce rates to feasible application levels in the field. Our study, combined with results from laboratory assays with SCN and RKN (Zasada, 2005; Zasada and Tenuta, 2004), indicate that the higher NVS rate suppressed $\mathrm{RKN}$ populations in soil conducive to ammonia accumulation after amendment. Tenuta and Lazarovits (2002b; 2004) showed ammonia to accumulate in soils of low organic matter and high sand content following addition of an organic nitrogen amendment (meat and bone meal). It is likely that NVS treatment will be most effective in such soils. Future studies will demonstrate whether NVS can decrease RKN populations and improve plant vitality and yields with varying soil conditions and changes in other environmental parameters.

\section{Literature cited}

Alptekin, Y. 2001. Distribution and control of soybean cyst nematode, Heterodera glycines Ichinohe (Tylenchida:Heteroderidae) in Ohio. M.S. Thesis, Ohio State Univ., Columbus.

APS Biological Control Committee. 2003. Commercial biocontrol products available for use against plant pathogens. 9 Mar. 2005. <http://www.oardc.ohio-state. $\mathrm{edu} / \mathrm{apsbcc} /$ productlist.htm $>$.

Blackburn, K., S.R. Alm, and T.S. Yeh. 1996. Avermectin $B_{1}$, isazofos, and fenamiphos for control of Hoplolaimus galeatus and Tylenchorbynchus dubius infesting Poa annua. J. Nematol. (Suppl.) 28(4S):687-694.

Cassel, D.K., Nielsen, D.R. 1986. Field capacity and available water capacity, $\mathrm{p}$. 901-926. In: A. Klute (ed.). Methods of soil analysis, part 1. Physical and mineralogical properties including statistics of measurement and sampling. Amer. Soc. Agron., Madison, Wis.

Cayrol, J.C., C. Djian, and J.P. Frankowski. 1993. Efficacy of abamectin $B_{1}$ for the control of Meloidogyne arenaria. Fundamental Appl. Nematol. 16:239-246.

Challis, G.L. and D.A. Hopwood. 2003. Synergy and contingency as driving forces for the evolution of multiple secondary metabolite production by Streptomyces species. Proc. Natl. Acad. Sci. 100(Suppl. 2):14555-14561.

Chubachi, K., M. Furukawa, S. Fukuda, S. Takahashi, S. Matsumura, H. Itagawa, T. Shimizu, and A. Nakagawa. 1999. Control of root-knot nematodes by Streptomyces: Screening of root-knot nematode-controlling actinomycetes and evaluation of their usefulness in a pot test. Jpn. J. Nematol. 29:42-45.

Chun, D. and J.L. Lockwood. 1985. Reductions of Pythium ultimum, Thielaviopsis basicola, and Macrophomina phaseolina populations in soil associated with ammonia generated from urea. Plant Dis. 69:154-158.

Dicklow, M.B., N. Acosta, and B.M. Zuckerman. 1993. A novel Streptomyces species for controlling plant-parasitic nematodes. J. Chem. Ecol. 19:159-173. 
El-Sherif, M.A., A.H.Ali, and M.I. Barakat. 1995. Suppressive bacteria associated with plant parasitic nematodes in Egyptian agriculture. Jpn. J. Nematol. 24:55-59.

Jansson, R.K. and S. Rabatin. 1998. Potential of foliar, dip and injection applications of avermectins for control of plant-parasitic nematodes. J. Nematol. 30:65-75.

Koenning, S.R., C. Overstreet, J.W. Noling, P.A. Donald, J.O. Becker, and B.A. Fortnum. 1999. Survey of crop losses in response to phytoparasitic nematodes in the United States for 1994. J. Nematol. (Suppl.) 31(4S):587-618.

Krechel, A., A. Faupel, J. Hallmann, A. Ulrich, and G. Berg. 2002. Potato-associated bacteria and their antagonistic potential toward plant-pathogenic fungi and the plant-parasitic nematode Meloidogyne incognita (Kofoid \& White) Chitwood. Can. J. Microbiol. 48:772-786.

Logan, T.J. and J.C. Burnham. 1995. The alkaline stabilization with accelerated drying process (N-Viro): An advanced technology to convert sewage sludge into a soil product, p. 209-223. In: D.L. Karlen, R.J. Wright, and W.O. Kemper (eds.). Agricultural utilization of urban and industrial by-products. ASA Spec.Publ. No. 58. ASA, CSSA, and SSSA, Madison, Wis.

McSorley, R. and R.J. McGovern. 2001. Effect of rhizobacteria on nematodes associated with impatiens. Proc. Soil and Crop Sci. Soc. of Florida 60:128-131.

Meyer, S.L.F. 1999. Efficacy of the fungus Verticillium lecanii for suppressing rootknot nematode egg numbers on cantaloupe roots. HortTechnology 9:443-447.

Meyer, S.L.F., R.N. Huettel, XZ. Liu, R.A. Humber, J. Juba, and J.K. Nitao. 2004. Activity of fungal culture filtrates against soybean cyst nematode and root-knot nematode egg hatch and juvenile motility. Nematology 6:23-32.
Meyer, S.L.F., S.I. Massoud, D.J. Chitwood, and D.P. Roberts. 2000. Evaluation of Trichoderma virens and Burkbolderia cepacia for antagonistic activity against root-knot nematode, Meloidogyne incognita. Nematology 2:871-879.

Netscher, C. and R.A. Sikora. 1990. Nematode parasites of vegetables. p. 237-283. In: M. Luc, R.A. Sikora, and J. Bridge (eds.). Plant parasitic nematodes in subtropical and tropical agriculture. CAB Intl., Wallingford, U.K.

Nitao, J.K., S.L.F. Meyer, and D.J. Chitwood. 1999. In vitro assays of Meloidogyne incognita and Heterodera glycines for detection of nematode-antagonistic fungal compounds. J. Nematol. 31:172-183.

Nitao, J.K., S.L.F. Meyer, J.E. Oliver, W.F. Schmidt, and D.J. Chitwood. 2002. Isolation of flavipin, a fungus compound antagonistic to plant-parasitic nematodes. Nematology 4:55-63.

Oka, Y., I. Chet, and Y. Spiegel. 1993. Control of the root-knot nematode Meloidogyne javanica by Bacilluscereus. Biocontrol Sci. Technol. 3:115-126.

Oka, Y. and S. Pivonia. 2002. Use of ammonia-releasing compounds for control of the root-knot nematode Meloidogyne javanica. Nematology 4:65-71.

Oka, Y. and S. Pivonia. 2003. Effect of a nitrification inhibitor on nematicidal activity of organic and inorganic ammoniareleasing compounds against the root-knot nematode Meloidogyne javanica. Nematology 5:505-513.

Ploeg, A.T. and M.S. Phillips. 2001. Damage to melon (Cucumis melo L.) cv. Durango by Meloidogyne incognita in southern California. Nematology 3:151-157.

Pridham, T.G., P. Anderson, C. Foley, L.A. Lindenfelser, C.W. Hesseltine, and R.G. Benedict. 1957. A selection of media for maintenance and taxonomic study of Streptomyces. Antibiotics Annu. 1956-1957:947-953.
Rhine, E.D., G.K. Sims, R.L. Mulvaney, and E.J. Pratt. 1998. Improving the Berthelot reaction for determining ammonium in soil extracts with water. Soil Sci. Soc. of Amer. J. 62:473-480.

Roberts, D.P., S.M. Lohrke, S.L.F. Meyer, J.S. Buyer, J.H. Bowers, C.J. Baker, W. Li, J.T. de Souza, J.A. Lewis, and S. Chung. 2005. Biocontrol agents applied individually and in combination for suppression of soilborne diseases of cucumber. Crop Protection 24:141-155.

Siddiqui, Z.A. and I. Mahmood. 1999. Role of bacteria in the management of plant parasitic nematodes: a review. Bioresource Technol. 69:167-179.

Tenuta, M. and G. Lazarovits. 2002a. Ammonia and nitrous acid from nitrogenous amendments kill the microsclerotia of Verticillium dabliae. Phytopathology 92:255-264.

Tenuta, M. and G. Lazarovits. 2002b. Identification of specific soil properties that affect the accumulation and toxicity of ammonia to Verticillium dabliae. Can. J. Plant Pathol. 24:219-229.

Tenuta, M. and G. Lazarovits. 2004. Soil properties associated with the variable effectiveness of meat and bone meal to kill microsclerotia of Verticillium dabliae. Appl. Soil Ecol. 25:219-236.

Tsao, P.H. and J.J. Oster. 1981. Relation of ammonia and nitrous acid to suppression of Phytophthora in soils amended with nitrogenous organic substances. Phytopathology 71:53-59.

Welacky, T.W. and E. Topp. 2001. Control of soybean cyst nematode Heterodera glycines with lime-stabilized municipal biosolids. Phytopathology 91:S145.

Zasada, I.A. 2005. Factors affecting the suppression of Heterodera glycines by $\mathrm{N}$ Viro Soil. J. Nematol.

Zasada, I.A. and M. Tenuta. 2004. Chemical-mediated toxicity of N-Viro Soil to Heteroderaglycines and Meloidogyne incognita. J. Nematol. 36:297-302 